\title{
Jurisprudential Approach to Criterion of Reproductive Legitimacy of the Wife by Foreign Gametes \\ Fathollah Ghorbani ${ }^{l}$, Elham Rezaee ${ }^{2}$
}

\begin{abstract}
Wife fertility by donation sperm or ovum is one of the new methods of laboratory fertility that experts benefit it to treat infertility of one of the spouses. In this technique, by supervision of doctor, wife will be able to fertility by getting donations sperm or ovum.

Infertility treatment of wife by foreign gametes causes some reactions and oppositions from Shia and Sunni scholars, especially this opposition is more precisely considered in relationship with wife fertility by foreign man's sperm in a way that more scholars treat this prick as adultery and oppose to maintaining chastity. By this citations, it is necessary to study if donation of gametes is unlawful? Or its permission is not out of mind? And by permission assumption, what compliance issues are its provisions? Is administration of this method interference in divine destiny, adultery and violation of caution in frvj? So, in this study, by firm answering to mentioned questions, we prove that benefiting this technique will be conditional lawful.
\end{abstract}

\section{Keywords}

Foreign Sperm, Foreign Ovum, Gametes, Infertility, Laboratory Fertility

Please cite this article as: Ghorbani F, Rezaee E. Jurisprudential Approach to Criterion of Reproductive Legitimacy of the Wife by Foreign Gametes. Iran J Med Law 2017; 11(42): 41-64.

1. Professor, Department of Theology and Islamic Education, Payamenoor University of Nahavand, Iran. (Corresponding author)

Email: Fathollah.ghorbani@yahoo.com

2. Lecturer, Department of Theology and Islamic Education, Payamenoor University of Nahavand, Iran.

Original Article Received: 28 October 2016 Accepted: 5 August 2017 


\section{رهيافتى فتهى به معيار مشـوعيت بارورى زوجه توسط كامت بيگانه}

\section{فتحالته قربانى'}

\section{الألام رضايى'}

\section{جكيده}

بارورى زوجه توسط اسيرم يا تخمك اهدايى يكى از شيوههاى نوين بارورى آزمايشعاهى محسوب

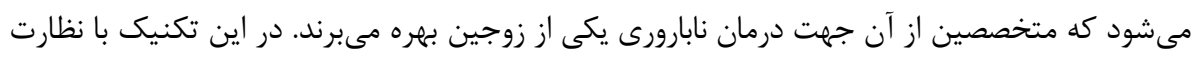

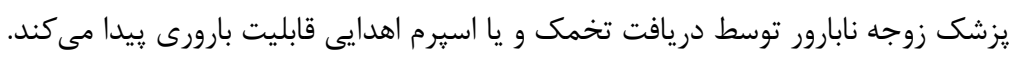

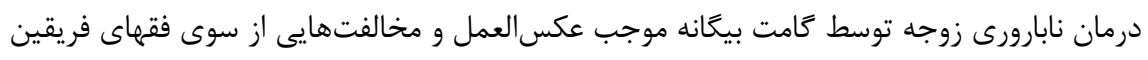

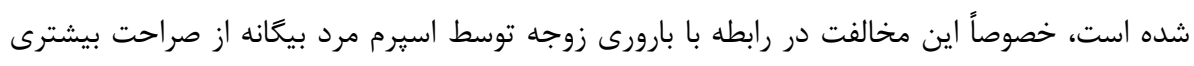

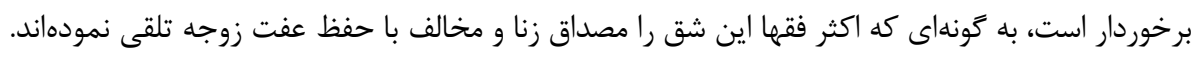

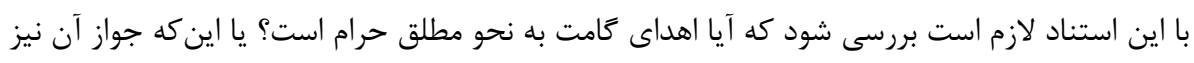

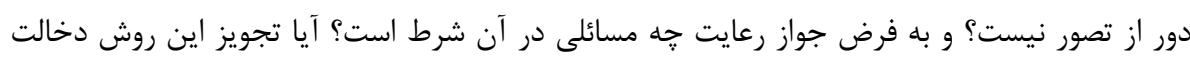

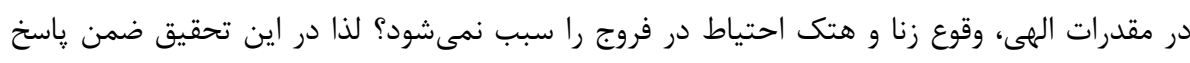

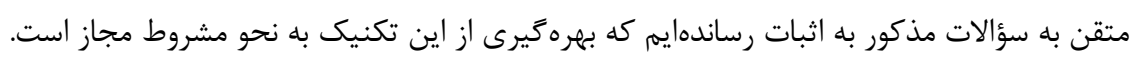

وازگَان كليدى اسبرم بيحانه، تخمك بيخانه، كامت، نابارورى، بارورى آزمايشگاهى

1. مدرس، كروه الهيات و معارف اسلامى، دانشكاه يِام نور، مركز نهاوند، نهاوند، ايران. (نويسنده مسؤول) Email: Fathollah.ghorbani@yahoo.com r. عضو هيأتعلمى، كروه الهيات و معارف اسلامى، دانشگاه ييام نور، مركز نهاوند، نهاوند، ايران.

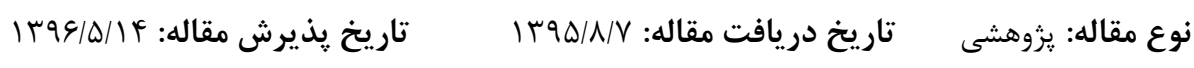


نابارورى واقعهاى است كه كمترين اثرش ايجاد يوجى در زوجين و در نهايت متاركه آنان از يكديگر است، اما در عصر حاضر كه پيشرفت و نبوغ بشرى در آن حاكم است ديكر به نابارورى

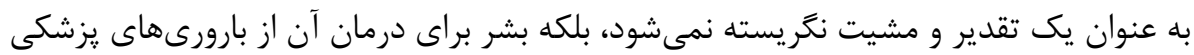

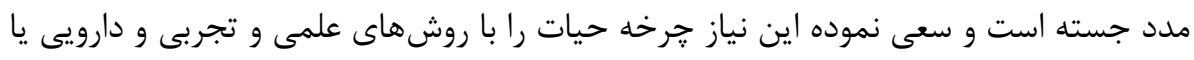
مذهبى درمان نمايد. با توجه به تأكيدى كه اسلام به ازدياد نسل دارد، نمى توان كَفت بارورىهاى يزشكى ممنوع

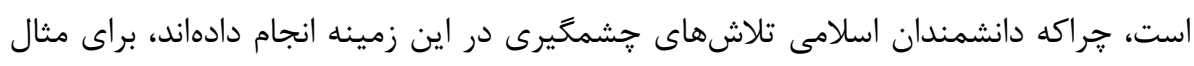

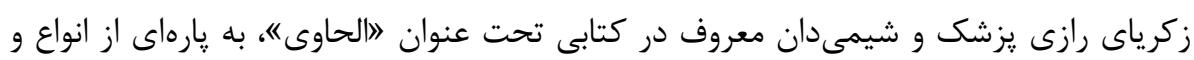

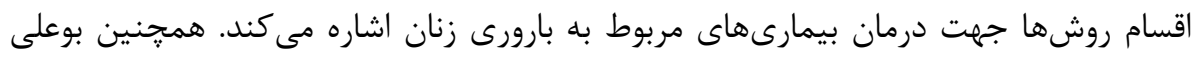

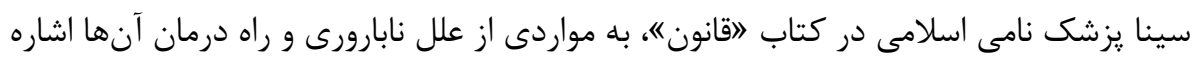

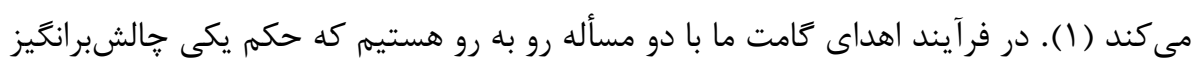
و ديخرى با اغماض نكر يسته شده است: ـ اسيرم غير شوهر (هترولوَ) (A.I.D: Artificial Insemination By Donor):

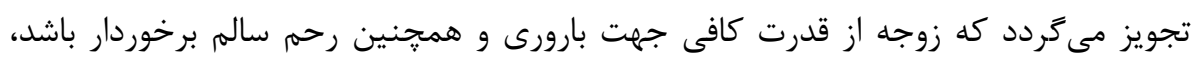

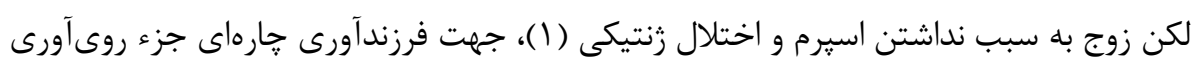

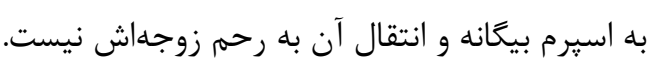

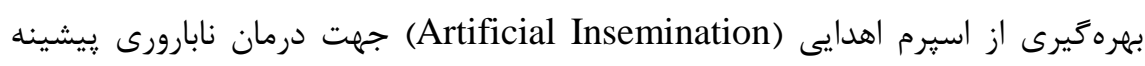

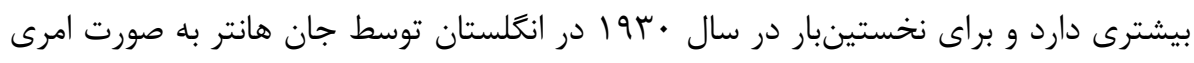

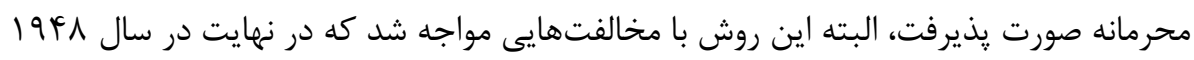
متوقف گرديد، مخالفين با استناد به دلايلى، جون ترس از اينكه از اين روش در در توليد

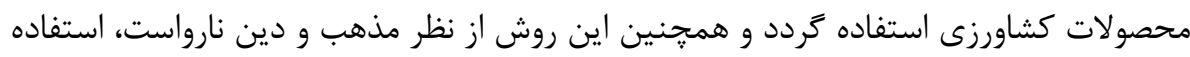

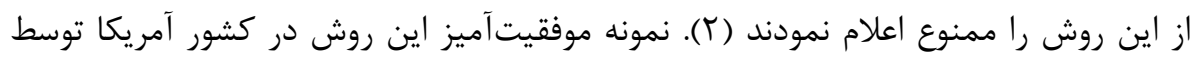

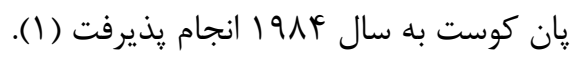

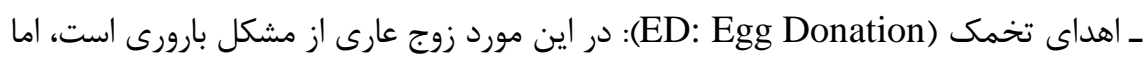

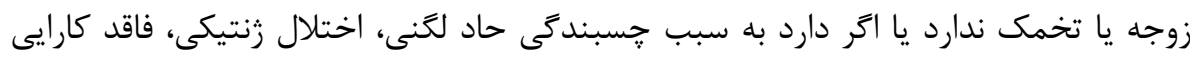


مناسب جهت بارورى است، براى رفع اين مشكل استفاده از تخمك بيخانه بيشنهاد مى

اهداى تخمك اولينبار در سال س1911 در ايالت كاليفرنيا انجام گرفت و در سال 1914 اولين فرزند حاصل از اين روش متولد گرديد و با توجه به اين كه · T تا ه درصد نابارورى زنان ناشى از اشكال در تخمك گذارى و تا حدودى ضعف ناحيه رحم است، استفاده از اين روش

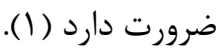
با عنايت به اين كه اهداى كامت يكى از روشهاى متداول درمان نازايى در برهه كنونى محسوب مىشود، در مطالعه حاضر حكم فقهى هر دو شق، يعنى بارورى توسط اسيرم مرد بيكانه و بارورى توسط تخمك زن بيحانه مفصلاً مورد واكاوى قرار مى خئيرد.

\section{مفهوم لغوى و اصطلاحى گامت}

وازه كامت يا ياخته جنسى از نظر لغوى به معناى سلول جنسى است كه در توليد مثل

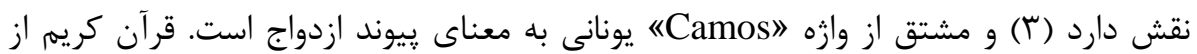
اين وازه به انطفه آميختهشده تعبير مى كند و در اصطلاح علم يزشكى، يعنى يك سلول

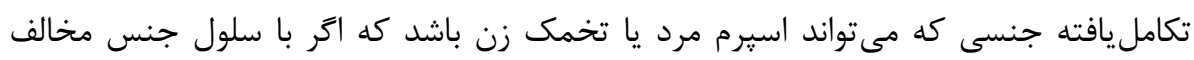

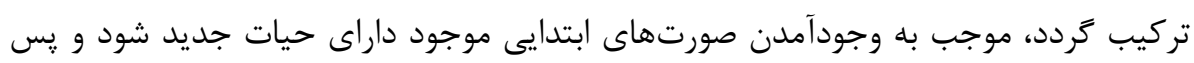

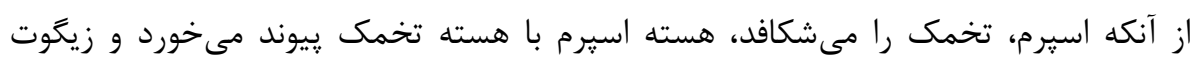
حاصل مىشود و رسيدن زيكوت به مرحله دو سلولى كه تا دو ماهكى ادامه دارد، رويان (Embryo)

\section{بيشينه فقهى}

اين گونه به نظر مىرسد كه اهداى كامت ٍِيديدهاى كاملاً جديد و ابداع دانشمندان غربى

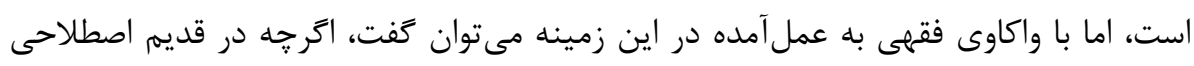
جون 》اهداى گامت" مطرح نبوده، اما مىتوان موارد مشابه اين روش رادر روايات مشاهده نمود.

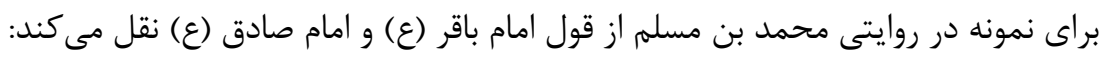


روزى جمعى از مردم از امام حسن (ع) سؤال كردند: مردى با همسرش مقاربت نموده و

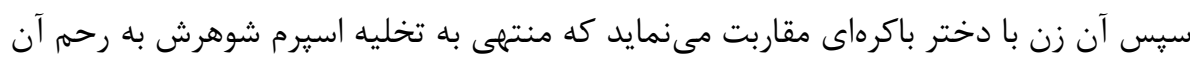
دختر باكره مىشود. بنابراين دختر حامله مىشود. اين خصوص خه به دستور مىفرماييد؟ امام

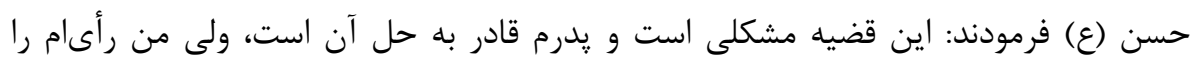
مى دهم، اگر درست بود، از لطف خدا و يدرم است، اتر اشتباه بود، من مقصرم، اما حكم: آن زن بايد به دختر باكره مهر المثل برداخت كند، به علت اين كه بكارتش به واسطه وضع حمل از بين رفته و در مرتبه بعد به علت اين كه آن زن شوهردار و محصنه است، سنكَسار مى گردد، اما دختر

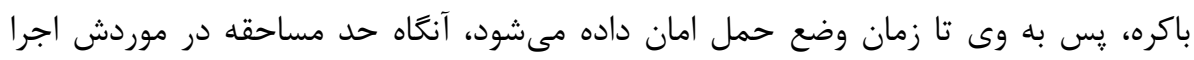

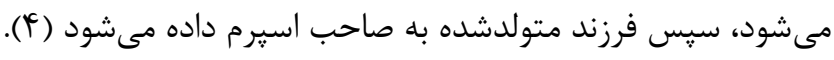

اهداى كامت از نظر فقهها در خصوص بارورى زن توسط كامت بيكانه فقهاى اسلامى سه ديدكاه ارائه دادهاند:

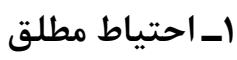

كروهى از فقها مذاهب اسلامى در ارتباط با بارورىهاى يزشكى از جمله اين فرآيند نظرى ابراز نداشته و به علت عدم وجود نص متقن و قوى در قرآن و روايات اسلامى اين زمينه صرفاً

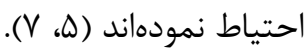

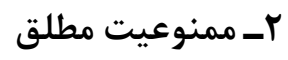

كروهى از فقها اهل سنت و شمارى از فقهاى معاصر شيعه معتقدند: اين فرآيند به علت

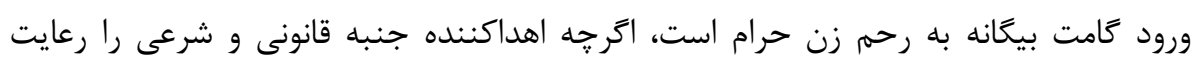
كرده باشد.

آيتا... فاضل لنكرانى مىفرمايد: كَرفتن نطفه از غير شوهر و همسر خود و تلقيح آزمايشًاهى

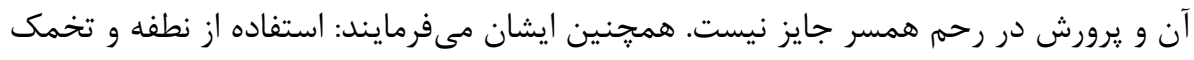

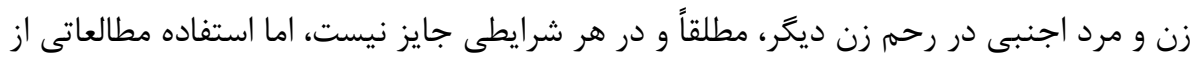

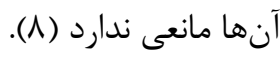


آيتا... مكارم شيرازى در حرمت بهره كيرى از تخمك بيكانه مىفرمايد: تركيب نطفه مرد با

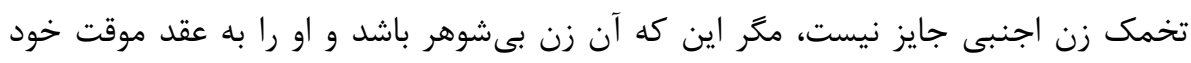

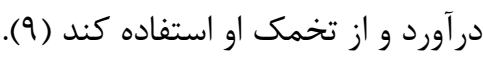

شيخ عطيه صقر فقيه اهل سنت اين روش را به علت اين كه مثل زناست و موجب اختلاط

$$
\text { نسب مىشود، حرام مى داند (• (1). }
$$

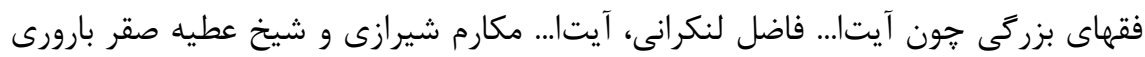

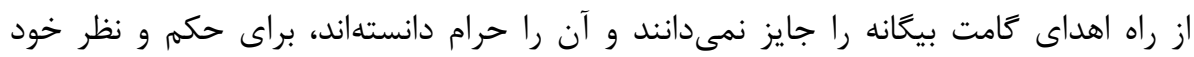
هلايل زير ذكر مى كنند.

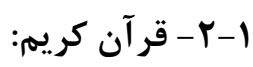

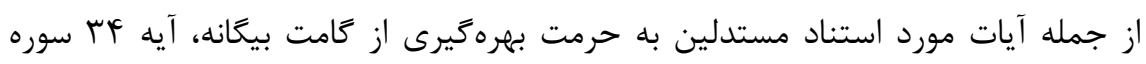

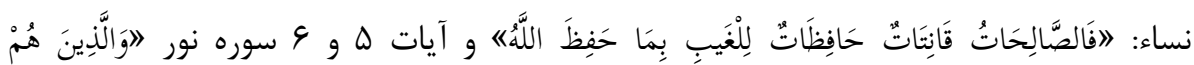

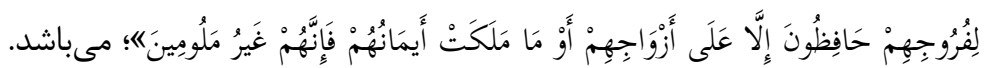

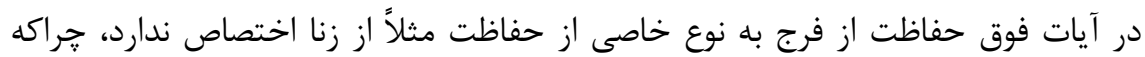

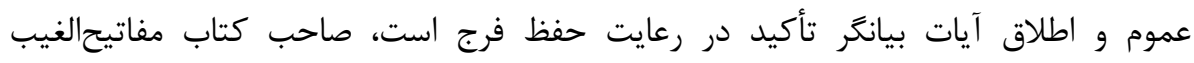

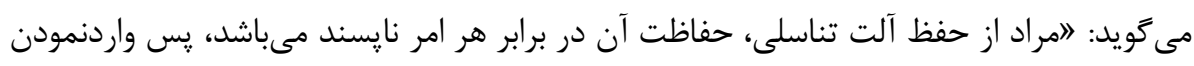

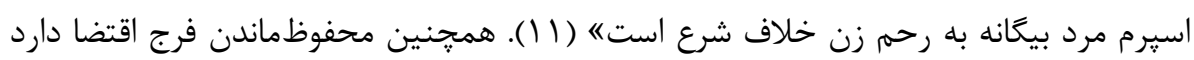

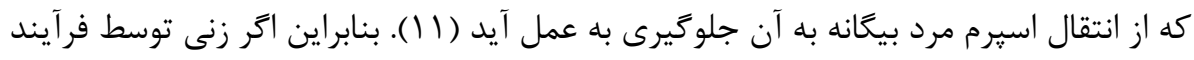

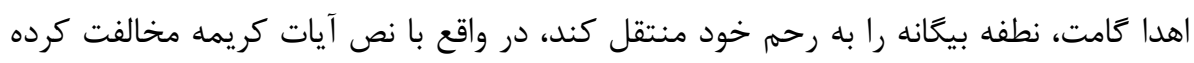

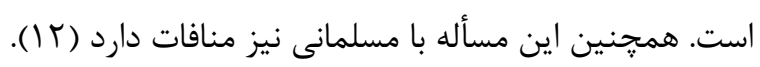
در تحليل نظر فوق بعضى علما برداشتى ديگر دارند كه قابل تأمل است:

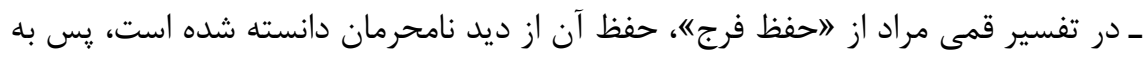
اين بحث مربوط نمىشود (r) (1).

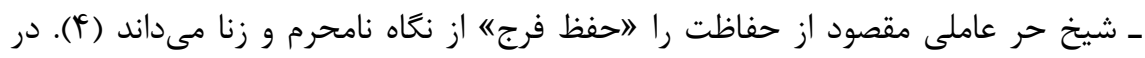

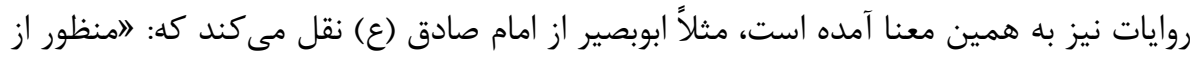

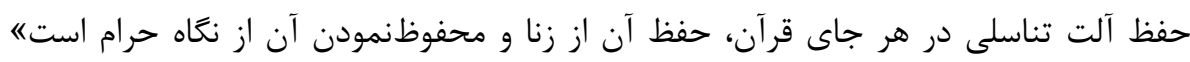


ـ مقصود آيات كريمه امورى مىباشد كه به وضوح تهديدى براى فروج است (4 ا، 11).

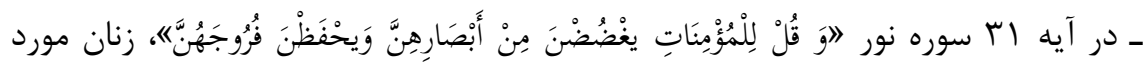

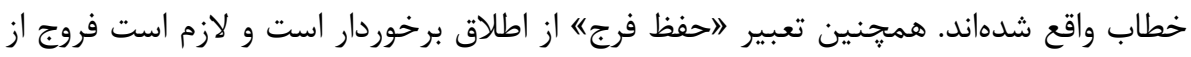
هر امر نايسندى محفوظ بماند (1) (1). اما اين استدلال صحيح نيست. شمارى از صاحبنظران در نقد اين استدلال بيان نمودهاند حكم مزبور در آيه مربوط به زنان نمىشود، جراكه در اين آيات مردان نيز مورد خطاب قرار كرفتهاند (ها). همجنين اتر اين فرآيند توسط خود زوجين انجام يذيرد، ديخر مشمول حكم

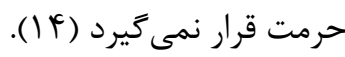

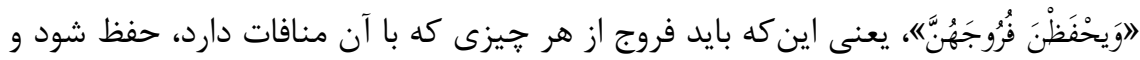

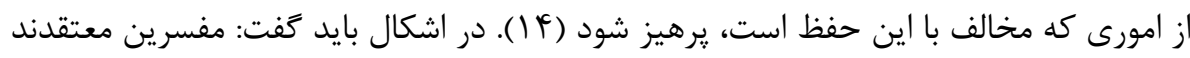
كه مقصود از حفظ فرج، حفاظت فرج از نكاه نامحرم و عمل شنيع (زنا) است (1).

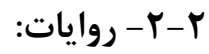
ـ در كتاب مستدرك الوسائل از قول نبى اكرم (ص) آمده است: المردى كه نطفه خود را به صورت نامشروع در رحم زنى وارد نمايد، كناهش بزرگتر از شرك به بارى تعالى استه (IV).

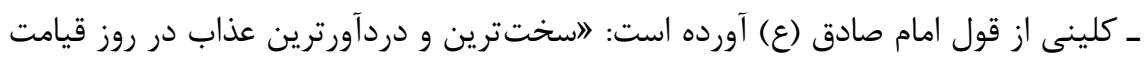

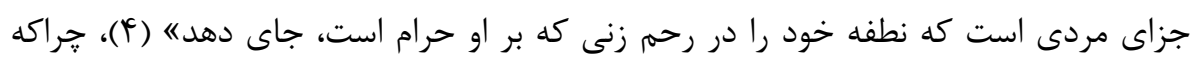

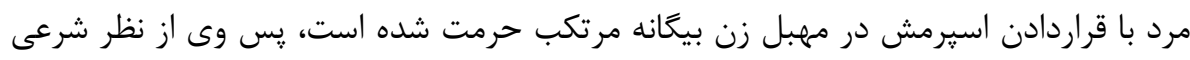

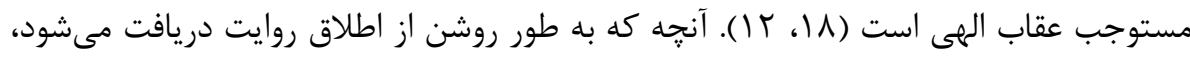

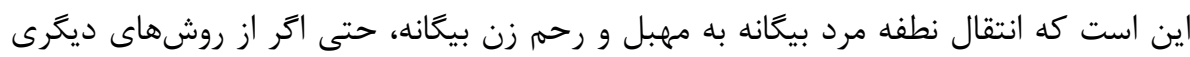
غير از جماع صورت يذيرد، از نظر اخلاق و شرع مردود است (ها) و باردارى بدين روش جايز

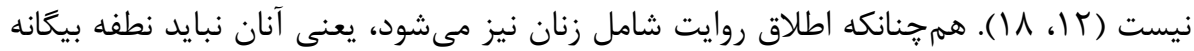

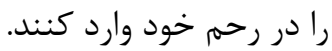
بر دلالت روايات فوق اشكالاتى وارد است: ـ آيتا... خويى بر اين عقيده است كه اين روايات دلالت بر حرمت زنا دارد (9 (1). بنابراين

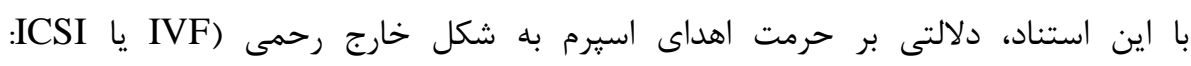


تكنيكهايى كه كامت يس از لقاح به رحم زن منتقل مى گردد) ندارند، جراكه از لحاظ شرعى و اخلاقى اين دو تكنيك اشكالى ندارد (1)).

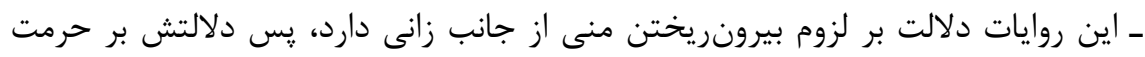

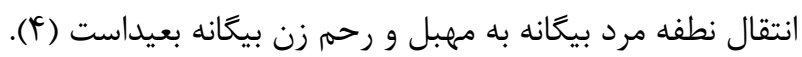
rــ اهداى كامت مصداق زناست

شمارى از فقهاى اهل سنت معتقدند اهداى كامت موجب آميختگى زنها با يكديكر مىشود، يس زنا و مردود است (• (). براى مثال شيخ محمود شلتوت بيان نموده است: الاين

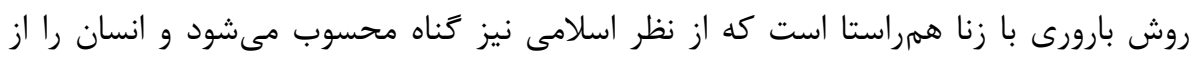

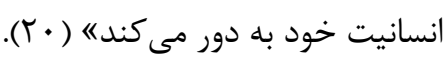
علت اين ديدكاهها اين است كه شمارى از فقهاى اهل سنت بيان كردهاند: الانتقال نطفه بارورشده شوهر قانونى به رحم همسرش كه توسط فرآيند تلقيح صورت مى گيرد، حرام است،

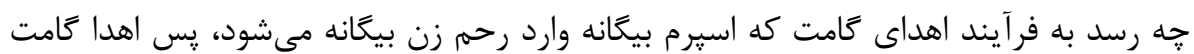

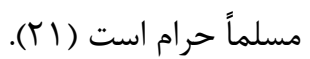

اكثر فقها شيعه اين فرآيند را زنا نمىداند (Tr). از اهل سنت نيز فقهايى جون مصطفى

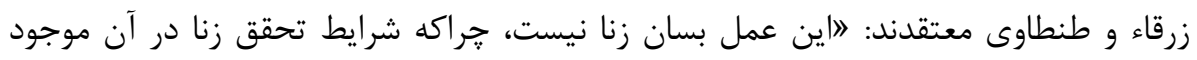

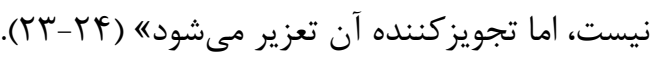

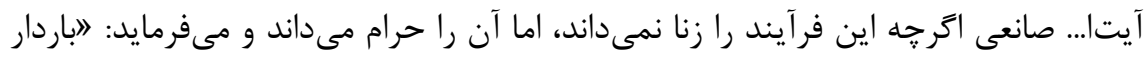
نمودن مصنوعى زن با نطفه غير شوهرش، يعنى واردنمودن نطفه مرد اجنبى به رحم زن، حرام

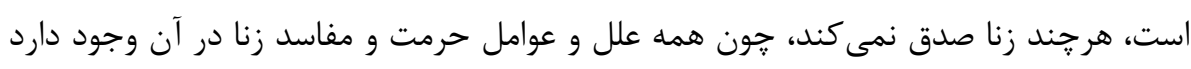
و فقيه حرمت را ازمذاق فقه مى يابد (Tه). F_ تجديد رسوم نايسند عصر جاهلى محمد على بار و شمارى ديكر از علما و فقهاى اهل سنت (ع) معنى معتقدند: الفر آيند مزبور

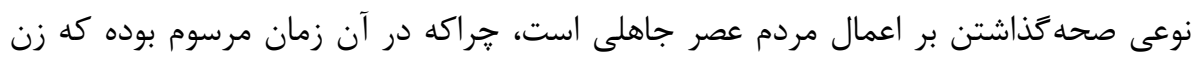

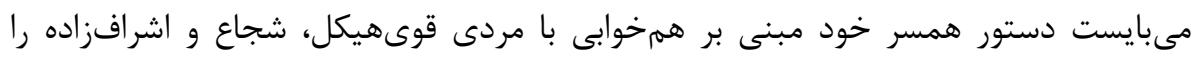

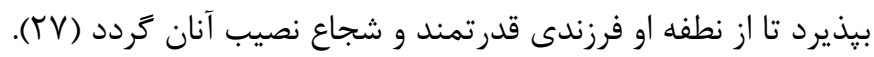


علامه جعفرى (ره) مىفرمايد: 》اگر اهداى اسيرم به زن بيكانه جايز و مباح باشد، در واقع

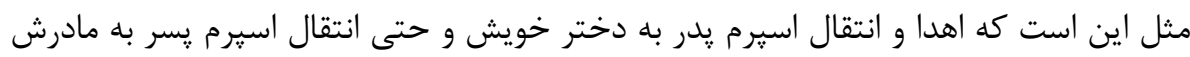

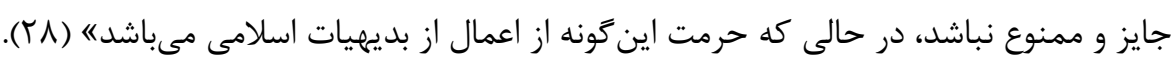
هـ ايجاد خدشه در شرافت انسان

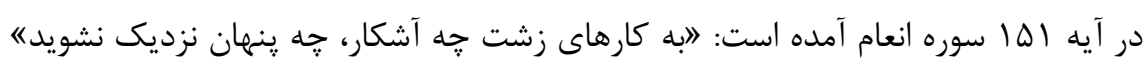

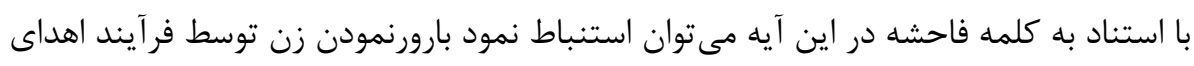

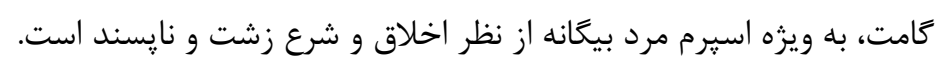

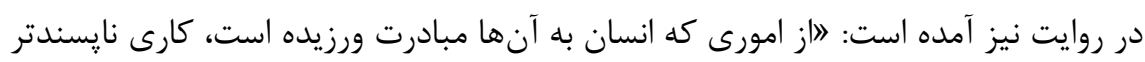

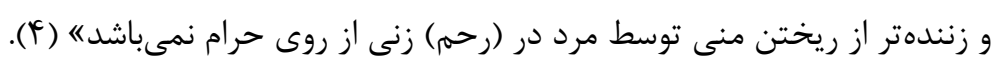

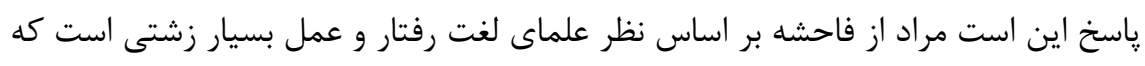

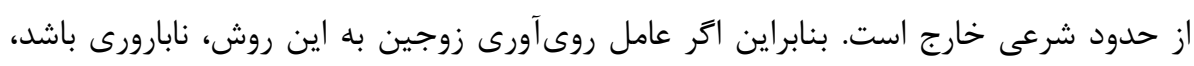

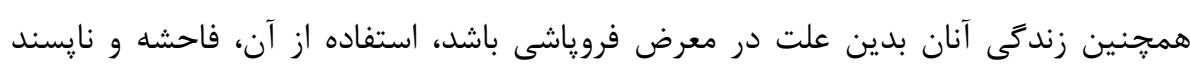

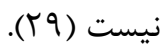
آيتا... صافى در اين راستا مىفرمايد: إيذيرش اين روش مغاير با اغراض قانونخذار اسلام در

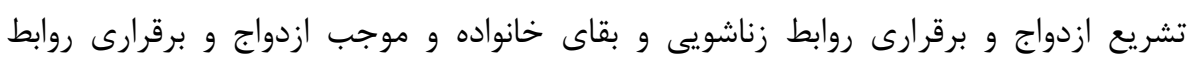

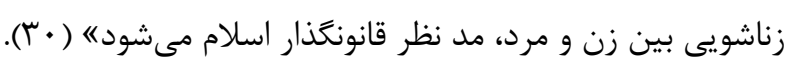

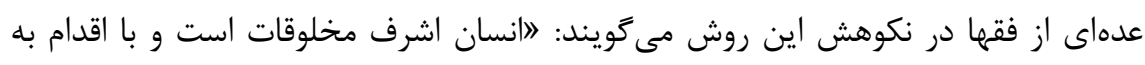

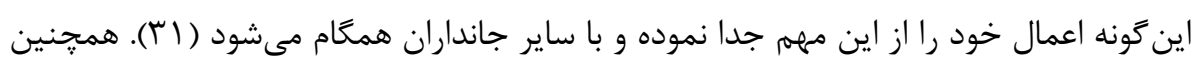

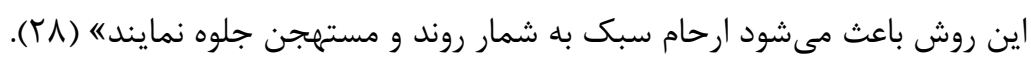

\section{9ـ تضييع حقوق كودى}

با استناد به آيه ه سوره احزاب كه مىفرمايد: إِيرخواندهايتان را به يدرانشان نسبت

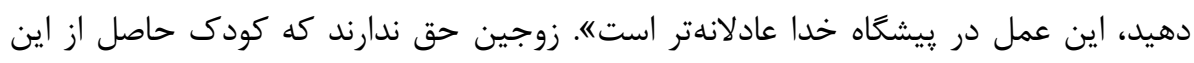

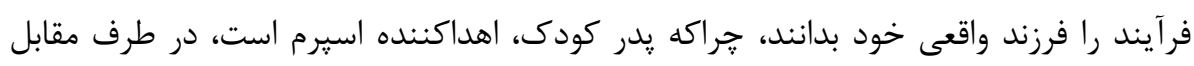

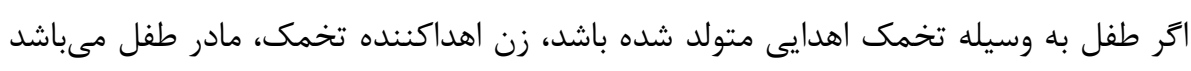

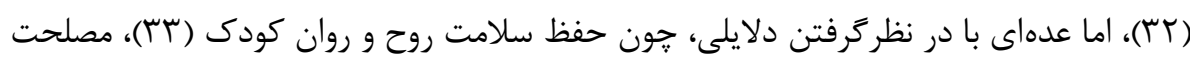

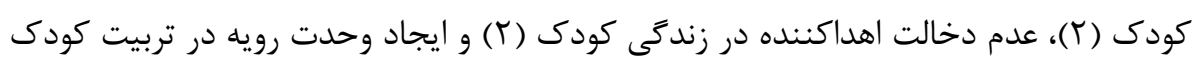


(YY) معتقدند: لزوجين مى توانند كودى را فرزند واقعى خود بدانند و حقايق را ينهان دارند، اما

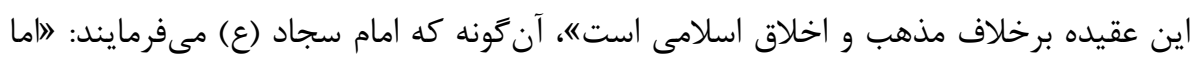
حق فرزند بر يدر اين است كه بداند او از توست و به تو نسبت دارده (ها؟). علامه جعفرى نيز

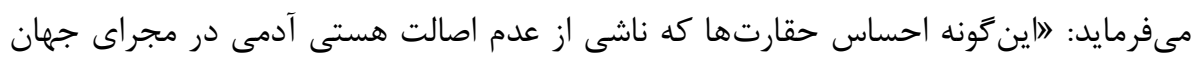
خلقت است، جه بسا تا آخر عمر دست از گريبان شخص برندارده (†^). بنابراين تجويز روشى

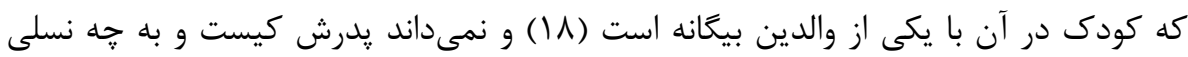
منتسب است، حقوق كودى راضايع مى كند (ه).

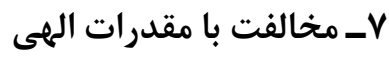

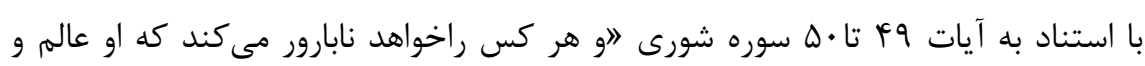

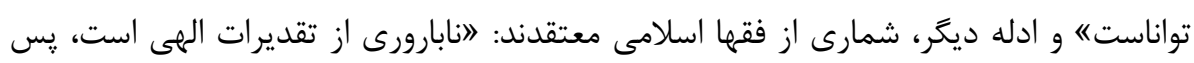

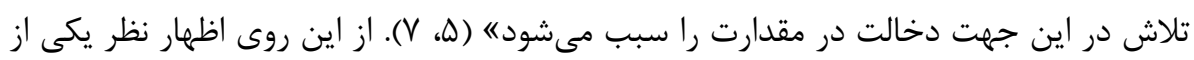

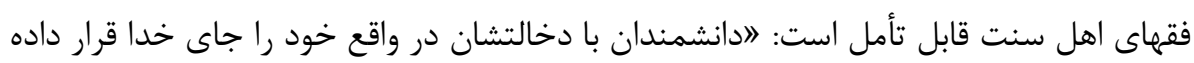
و موجب تغيير در اصالت بشر و اختلاط نسب شدهاند و اين دخالت از نظر عقلى مردود استها، لهان،

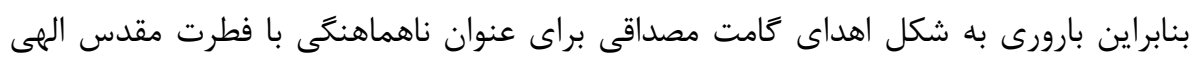

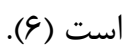
از باب سدّ ذرايع نيز مى توان حرمت را استنباط نمود، هراكه اكر فرض نماييم اهدا كامت

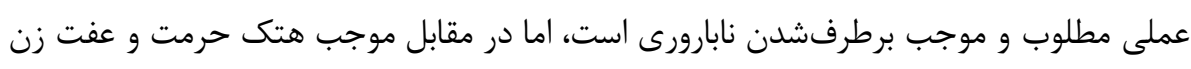
مىشود كه اين امور حرام مى باشند (צَ).

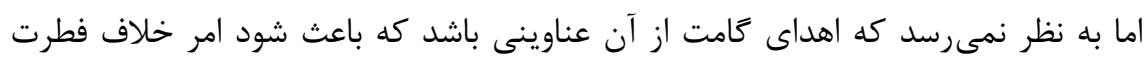

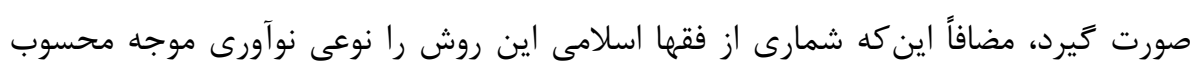

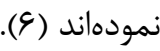

\section{1ــ مخالفت با احتياط در فروج}

بر اساس مبانى علماى اخلاق، زن بايد خصوصاً در زمينه لاحفظ فرجه اهتمام لازم را به

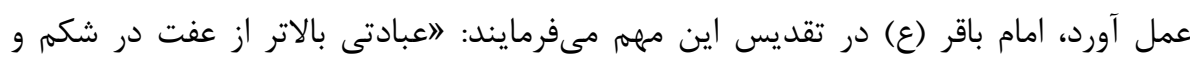

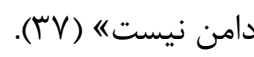


سال يازدهم، شماره جهلودوم، پياييز

در آيات قرآن از جمله آيه له سوره مؤمنون نيز محافظين فروج به رستكارى نويد داده

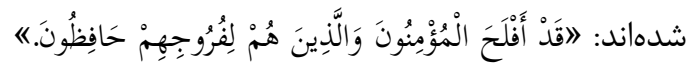
فحواى نصوص، حفظ فرج و حساسيت نسبت به آن را نوعى تكليف دانسته و در موارد

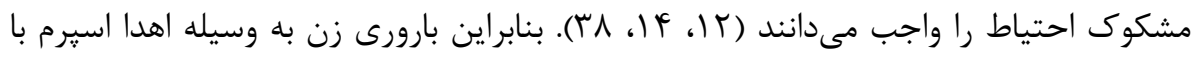
عفت ناسازًار است (9))، در روايات ذيل حساسيت ائمه (ع) نسبت به بحث فروج مشهود است:

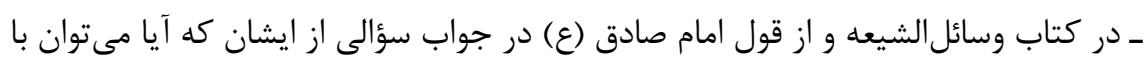
زنى كه برخلاف شرع اسلام طلاق داده شده است، ازدواج نمود، ايشان نهى مى كنند و دستور به

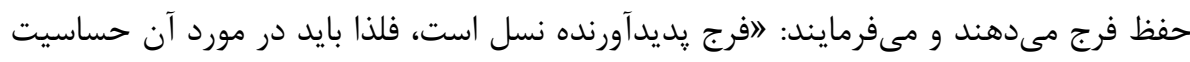

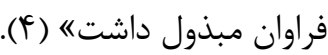
- روايتى در باب وكالت در امر نكاح و از قول امام صادق (ع) در جواب سؤالى مبنى بر اينكه زنى به مردى وكالت داد تا او را به ازدواج كسى درآورد، امام (ع) در جواب فرمودند: اازدواج

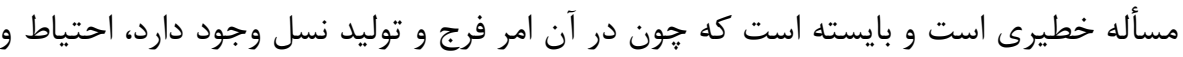
حساسيت شوده (†). قائلين به حرمت با استناد به روايت فوق بيان نمودهاند: ابراى تجويز اين روش هيج دليلى وجود ندارد، يس حرام استه (4) (1).

\section{9ـ تغيير در خلقت خدا}

قائلين به حرمت با استناد به آيات قرآن بيان نمودهاند اگر فرزندى توسط فرآيند اهداى

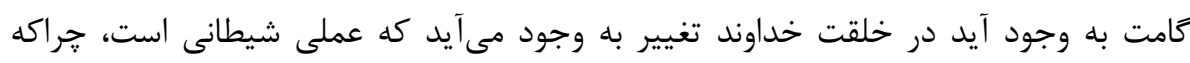
شيطان در آيه • ب سوره روم كفته است: لادر انسانها وسوسه ايجاد مى كنم و به آنان فرمان

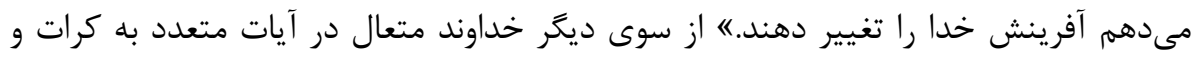
مرات راه توليد نسل و ازدياد آن را در ازدواج صحيح دانسته و بىشك هر راهى غير از اين مورد با قانون الهى در تضاد و محكوم به بطلان است، يس اهداى كامت نوعى عمل شيطانى و تبديل

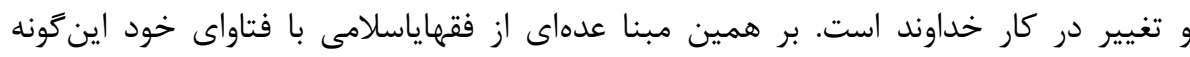

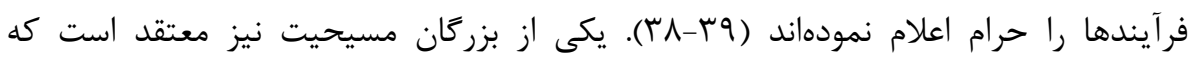

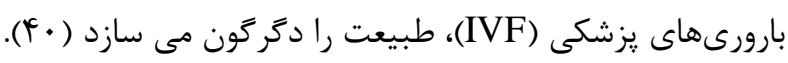

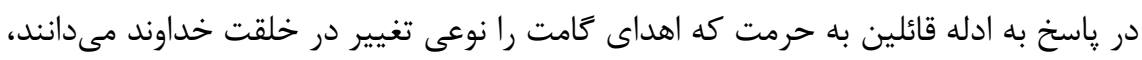

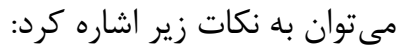


سال يازدهم، شماره جهلودوم، باييز 97\%1

ـ تغيير در خلقت خداوند زمانى محقق مى گردد كه فعل شيطان با خلقت خداوند معارضه

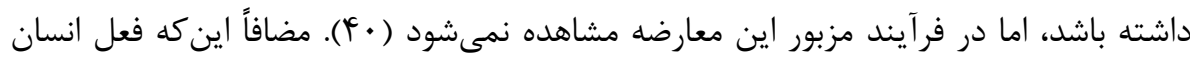
نيز تجلى فعل خداست. ـ در آيات قرآن، خداوند در خلقت انسان از تنوع بهره برده است، مثلاً در آيه · ب سوره روم

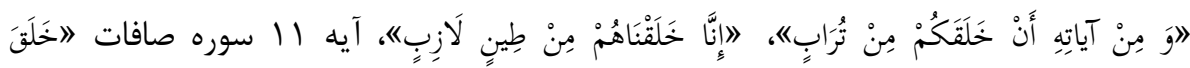

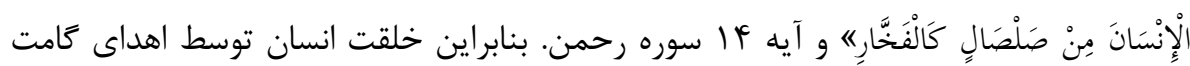
نيز نوعى تنوع در آفرينش الهى است.

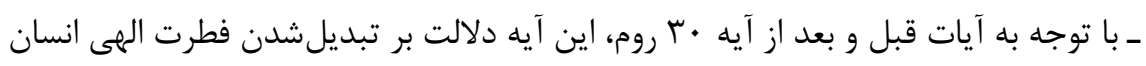

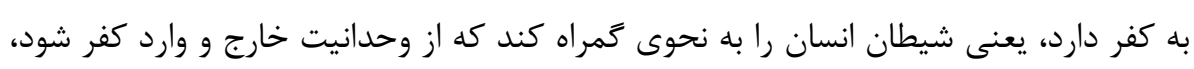

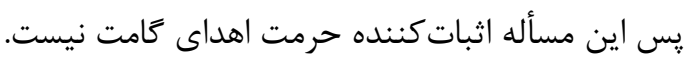

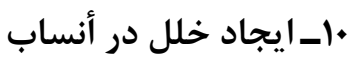

با توجه به اين كه معيوببودن اسيرم مرد، ابتلاى شوهر به بيمارى زنتيكى و وراثتى، عمده

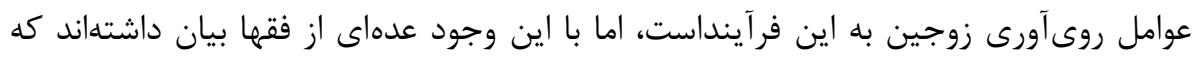
اين عوامل موجب تجويز فرآيند مزبور نمىشود، جراكه موجب اختلاط اسيرم و در در نتيجه اختلاط نسب مى كردد و با توجه به حساسيتهاى شارع نسبت به مسأله نسب، هر كونه آميزش

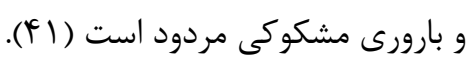

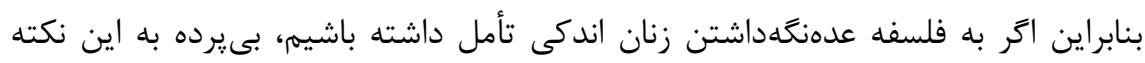

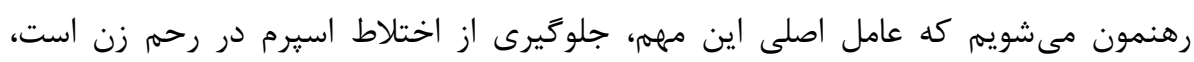

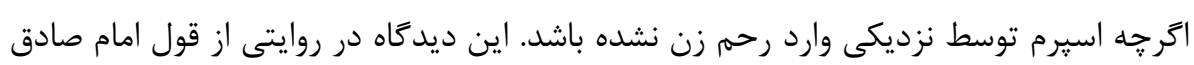

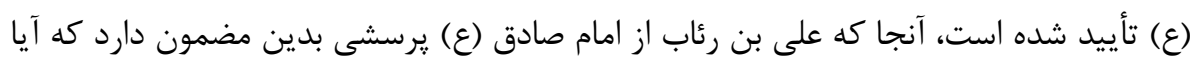

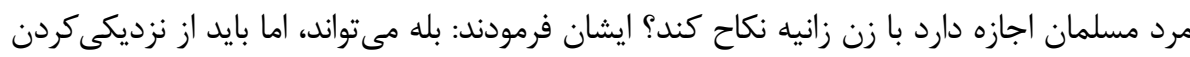
تا يقينداشتن به باردارنبودن و يا اكر باردار است تا فارغشدن امتناع ورزد (\$).

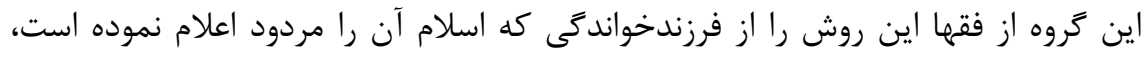

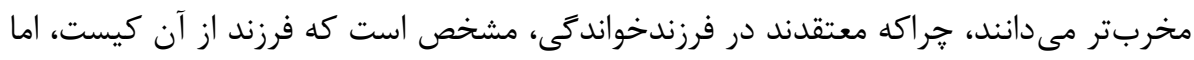

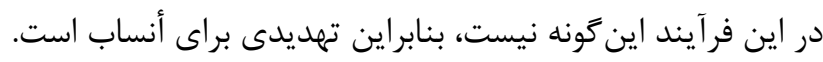


شمارى ديكر از فقها بيان نمودهاند به فرض كه استفاده از اين فرآيند مجاز باشد بايد از آن

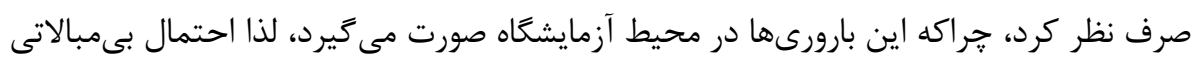

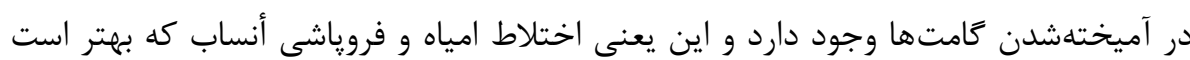

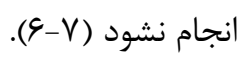

\section{Iا_ انحراف در رسالت نكاح}

مقتضاى فطرت الهى اين است كه انسان به وسيله نكاح صاحب فرزند شود. در آيه VT سوره

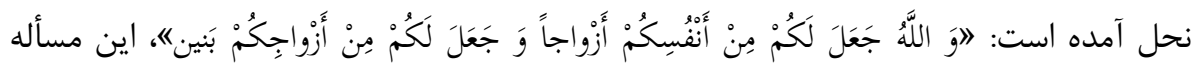

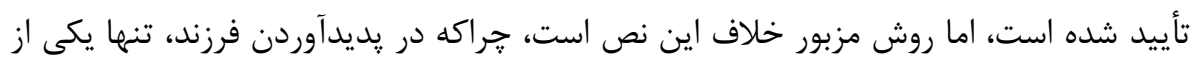

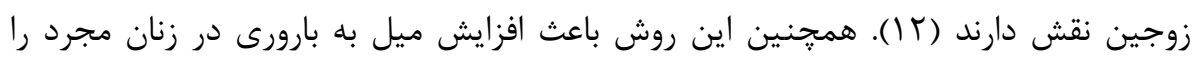

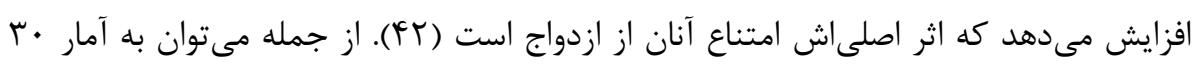

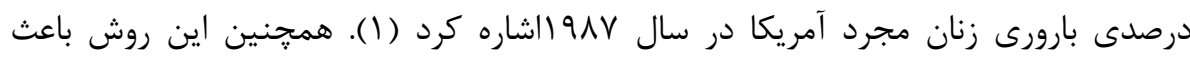

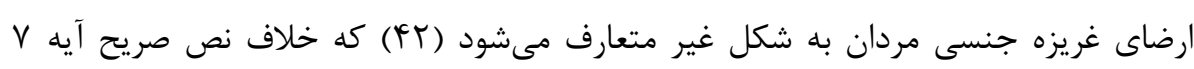
سوره مؤمنون است. شمارى از فقها شيعه معتقدند جون اين روش رسالت نكاح را خدشهدار مى كند، در نتيجه حرام است، آر جه به نص صريح قرآنى و روايى جهت تأييد مدعاى خود دست بيدا نكردهاند، اما

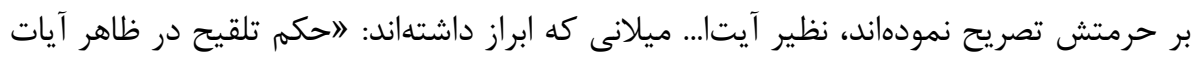

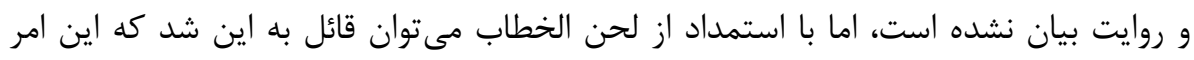

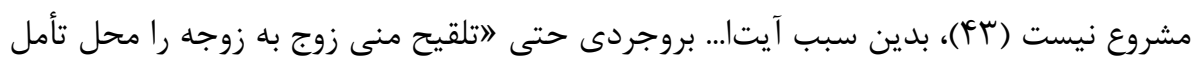

$$
\text { و اشكال مى دانند." }
$$

همجنين فقهاى اسلامى در بيانات خود براى نكاح دو ثمره مههم برمىشمارند: المرتفعنمودن

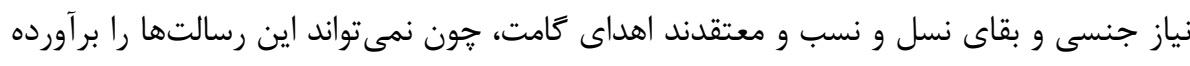

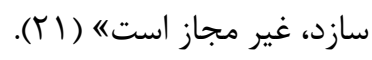
rا- وقوع حرمت

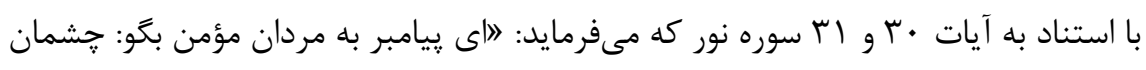

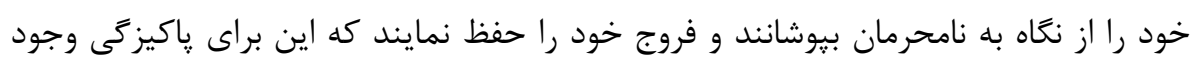

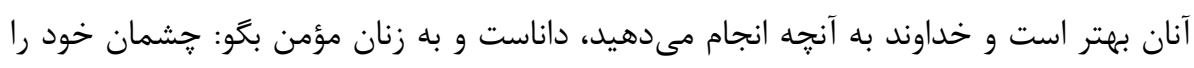


(از نعاه شهوتانگيز) بيوشاند و فروج خود را حفظ دارنده، مىتوان ابراز داشت: نظرافكندن به

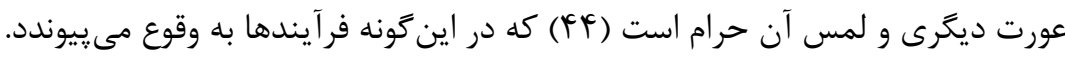
در روايات ذيل نظرانداختن به عورت ديگرى مذموم دانسته شده است: - روايت حريز: هيج مردى به عورت برادرش نظر نيندازد (†). ـ روايت حسين به زيد از امام صادق (ع): نبى اكرم (ص) فرمودند: لاى على (ع) هيج كاه بدون ساتر داخل حمام نشو، جراكه نخاه كننده به عورت و همجنين شخص منظور مورد لعن

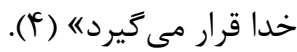
اما با استناد به قاعده اضطرار مى توان اشاره كرد: اضطرار موجب رفع حرمت حمت مىشود، درمان نابارورى يك ضرورت محسوب مىشود، يس شخص، مرتكب حرمت نشده است (9). همجنين

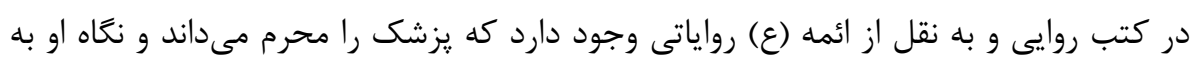
عورت شخص جهت معالجه را مجاز مىداند (9).

\section{مشروعيت مشروط}

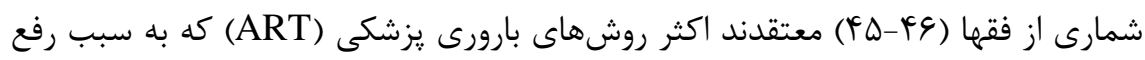

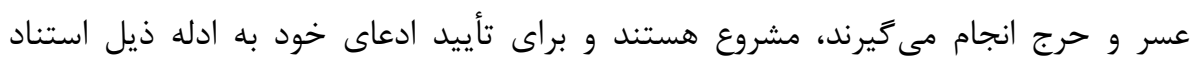
نمودهاند: إـ اصل اباحه و برائت آيتا... حرم ريناهى از جمله فقهاى معاصراست كه اين روش را جايز مى داند و آن را از جمله

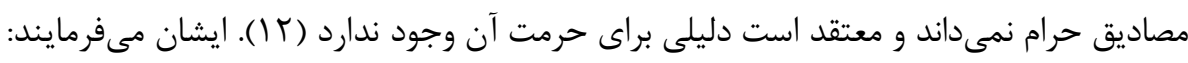
"اما دليل بر حرمتساختن، نطفه بجٍه از دو آب حرام نداريمه ( ( I). آيتا... خامنهاى در اينباره بيان فرمودهاند: لاستفاده از اسيرم شخص ثالث جهت درمان ناز ايى و تلقيح فىنفسه منع شرعى ندارد و فرقى ميان بستغان شوهر و افراد ديكر در اين باره

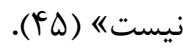
در كتب روايى نيز احاديثى وجود دارد كه بيانكر اين مسأله است كه اكر در ارتباط با حرمت مسأله دليلى نباشد، حلال و حدأقل مباح است. از جمله روايت عبدالله بن سنان كه از امدام 
صادق (ع) نقل مى كند كه ايشان فرمودند: اهر جيزى بر توحلال است، مكر اين كه بعينه بدانى

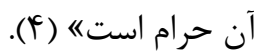
با استناد به روايت فوق مىتوان كَتت: لاما دليلى را كه به طور واضح بر حرمت اين مسأله دلالت كند، نيافتهايم، پِ بارورى به شكل اهداى كامت بىاشكال استه (YV).

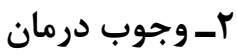
فقه يوياى اسلام كه بركرفته از جشمه زلال و جوشان قرآن كريم و روايات ائمه (ع) است، مشروعيت درمان را مورد تأكيد قرار داد. در سيره نبوى نيز ماهيت درمان دان ماندان مورد تأييد قرار

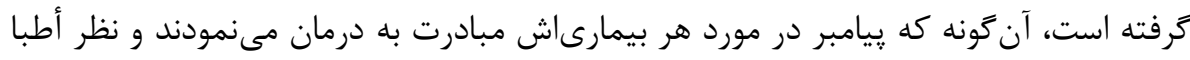

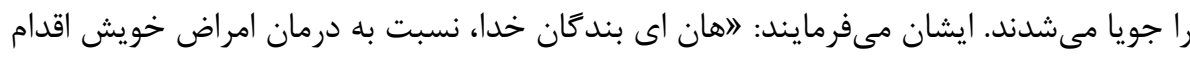
نماييد، زيرا كه يروردكار هيج مرضى قرار نداده است كه درمان نداشته باشد، مكر يك مرض و

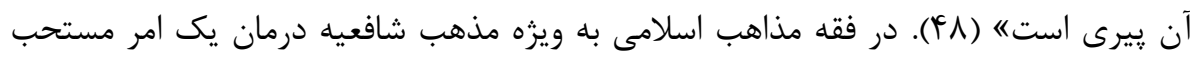

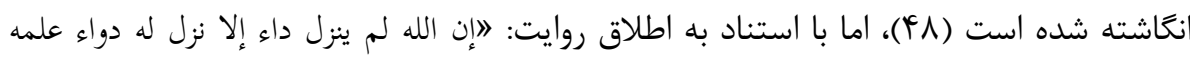

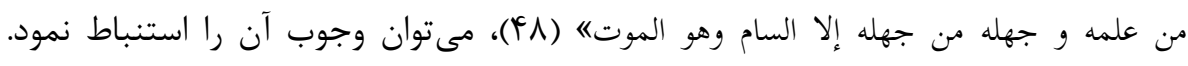
همجنين روايات فرآوان ديخرى نيز وجود دارد كه مضمون آنها بيانكر اين مههم است كه بهر براى

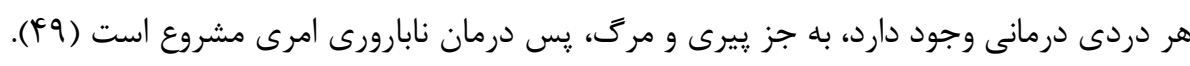

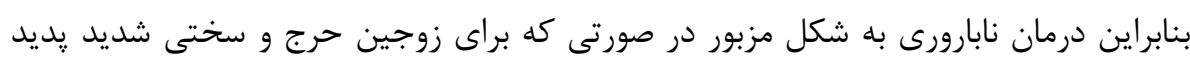

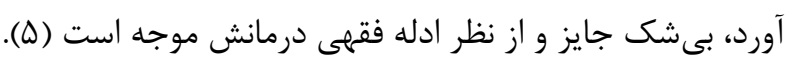

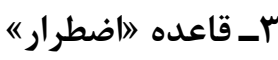
قاعده عمومى مذكور بيانكر اين مهم است كه احكام اوليه، جون حرمت يا وجوب در صورت رخداد اضطرار جاى خود را به جواز داده، لذا در اين شرايط ارتكاب حرمت يا عدم انجام واجب

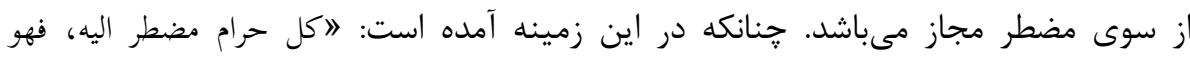
حلاله، در ذيل نيز به رواياتى اشاره شده است كه بر مبانى فوق صحه مي كذاردارد:

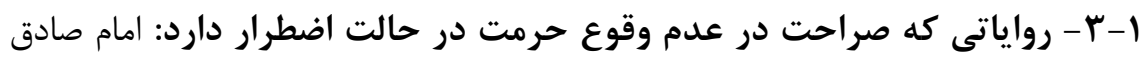

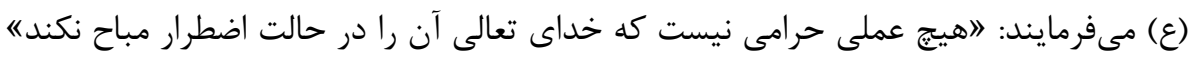


r-r-r- رواياتى كه در آنها عدم رفع اضطرار كفر تلقى شده است: امام صادق در اين

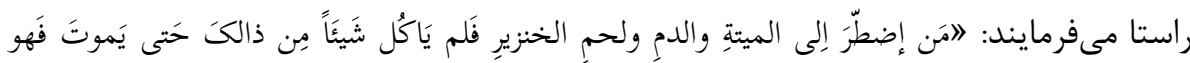

در نتيجه با اتكا به مستندات فوق مىتوان ابراز داشت به فرض كه بارورى به شكل اهداى كامت حرام باشد، لكن جون زوجين عقيم در شرايط اضطرار قرار دارند، مجاز هستند كه بهان نابارورى خود را با دريافت كامت بيگانه درمان نمايند.

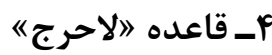

بروز ناسازگارى و اختلاف بين زوجين كه ناشى از نابارورى است، به حدى زندكى آنان را با

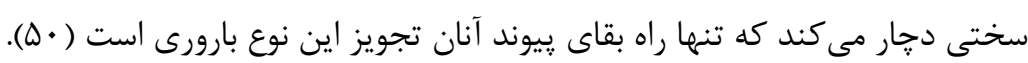

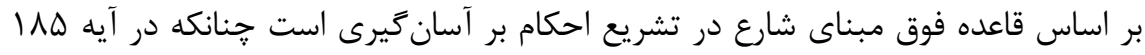

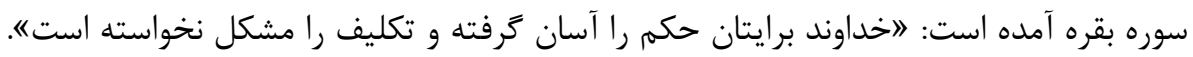

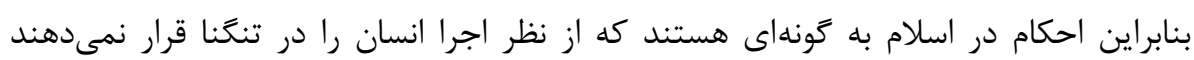
(ن) (DI). آيات قرآنى به شكل صريح و غير صريح عسر و سختى را امرى منفى تلقى مىنمايند،

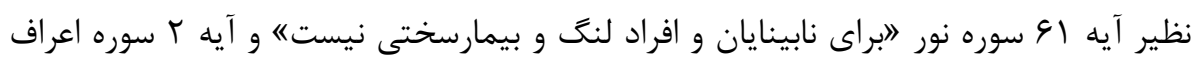

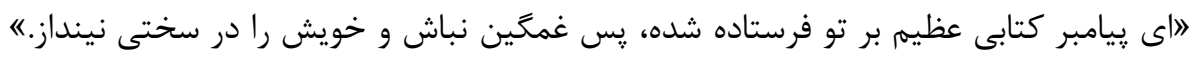

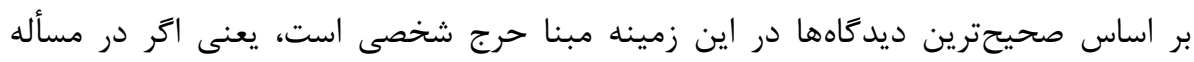
حكمى باعث ايجاد سختى براى شخصى شود، براشته مىشود ( (1)).

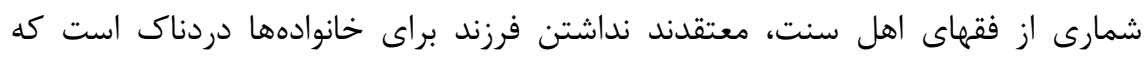

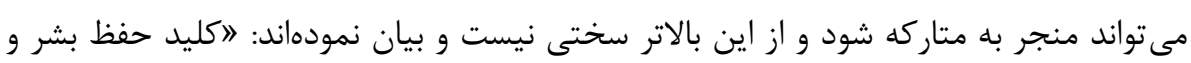

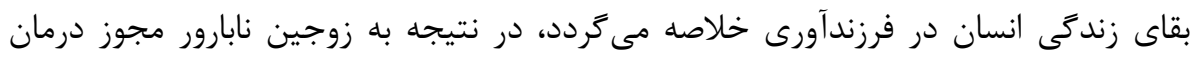
داده، جراكه معتقدند شارع اين رويكرد را تجويز نموده استه (QT).

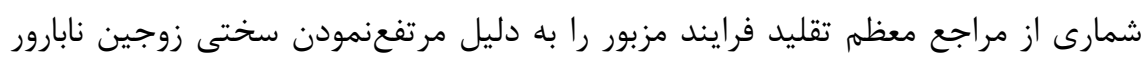

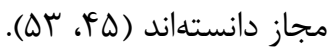

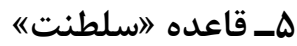
قاعده تسليط كه متخذ از حديث شريف نبوى 》الناس مسلطون على اموالهم/ است، به شهادت فقهاى اسلامى قاعدهاى عقلى به شمار مىرود و حاكى از دو مسأله است: همه دخل و تصرفات 
سال يازدهم، شماره جهلودوم، پياييز

شخص در امورتحت تصرفش مباح است. همجنين هر نوع بهرهورى از مال و منافع ديكران

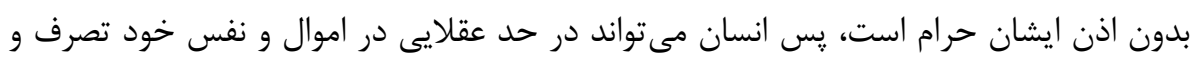

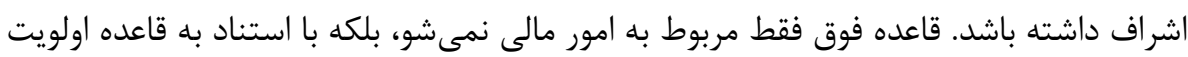

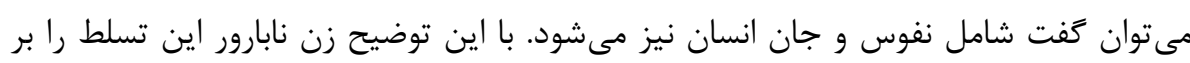
جان و رحم خود دارد كه با دريافت كامت بيگانه، نابارورى خود را رفع كند (DF).

\section{ملاكىهاى مشروعيت بارورى زوجه توسط گَامت بيكانه اــ اهدا با رعايت موازين شرعى صورت كيرد}

رعايت اخلاق اقتضا مىنمايد كه كامت بهره كيرىشده از زنا نباشد (N) و نحوه كرفتن اسيرم بيكانه غير شرعى نباشد، يعنى منتج از مبادرت عمل زناشويى باشد (^). همجنين ملاحظات

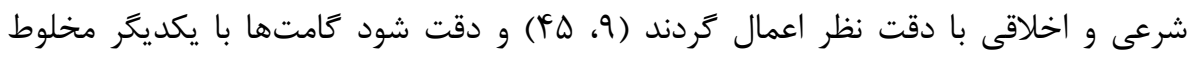

آيتا... خامنهاى مىفرمايند: التلقيح زن از طريق نطفه مرد نامحرم فىنفسه اشكال ندارد،

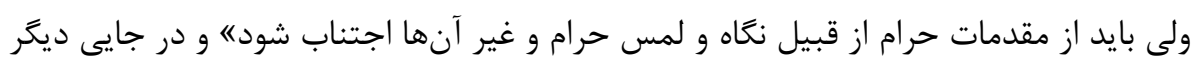

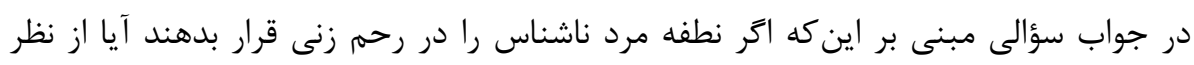

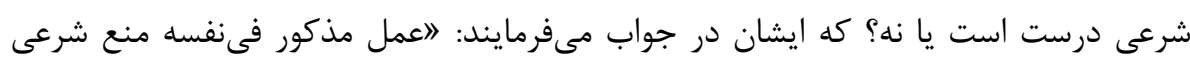
ندارد، لكن از لمس و نظر حرام بايد اجتناب شوده (هاب (l). r_ كَامت به روش ICSI انتقال يابد

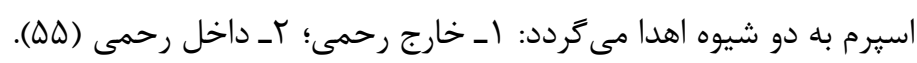

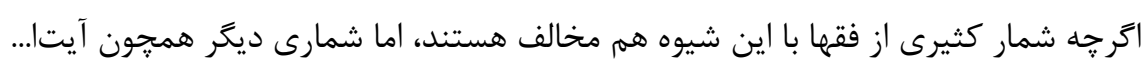

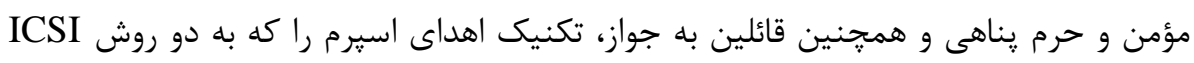

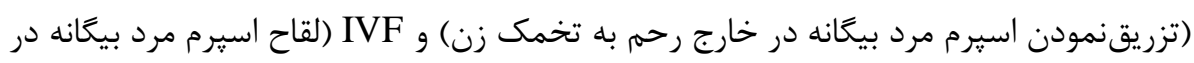

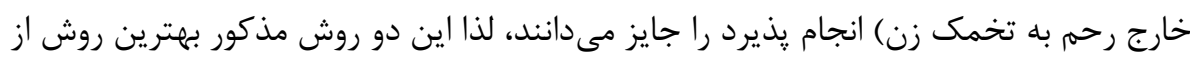

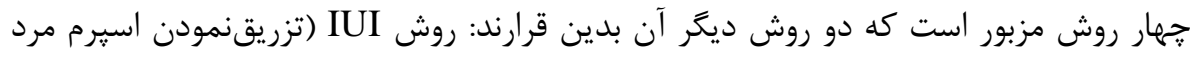

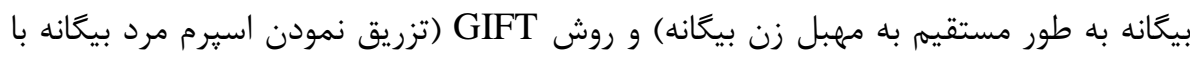
تخمك زن بيعانه به صورت داخل رحمى) (هڤ). 
اما روش IUI خلاف مبانى فقهى است. رضايت زن كيرنده و عدم رضايت او تأثيرى در

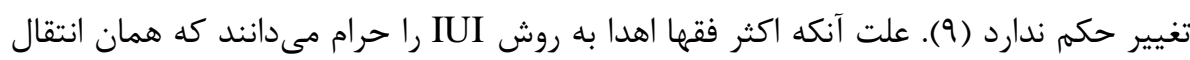

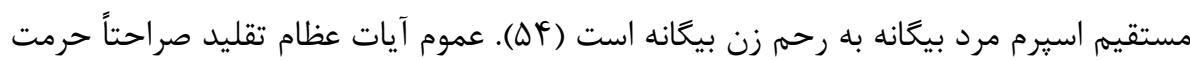

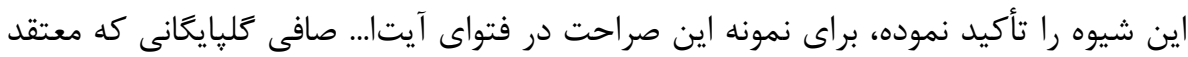
است شيوه IUI جرم است و يزشك تجويزكننده اين روش مستحق تعزير است، مشهود است

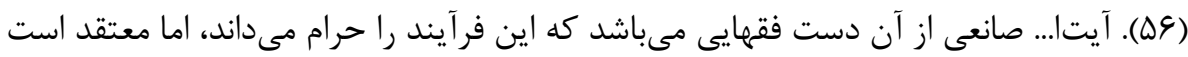

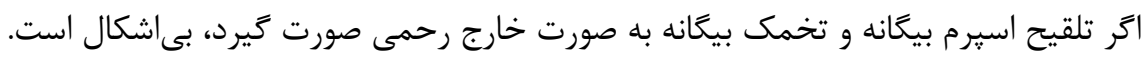
r_اهدا توسط محرم زن (شوهر ) صورت كيرد

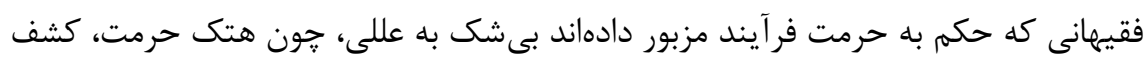

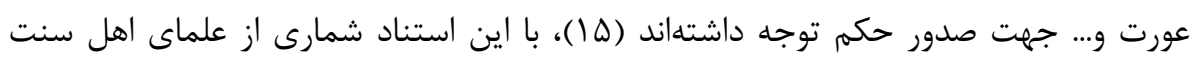
انجام اين فرآيند را در صورتى مجاز مىدانند كه توسط شوهر زن انجام گيرد، لكن در صورت

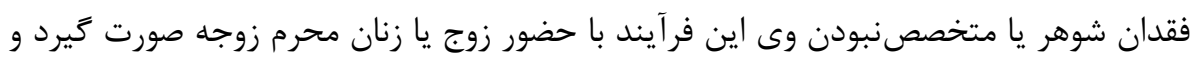

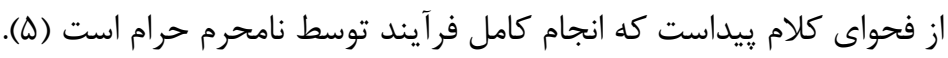

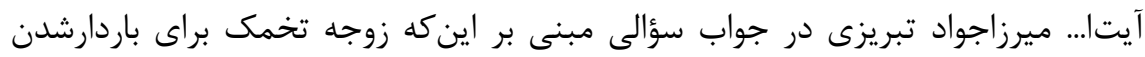

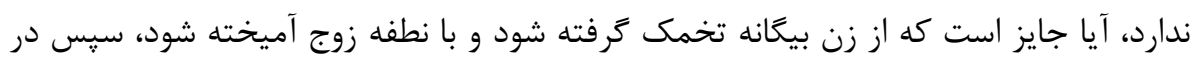

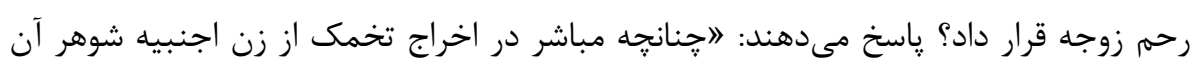

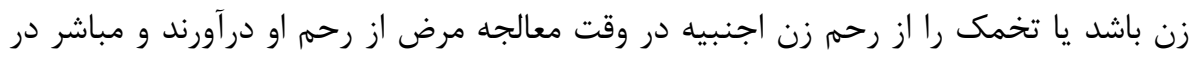

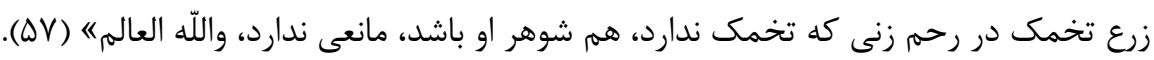

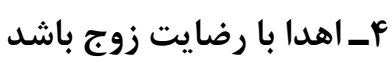

شمارى از فقهاى مذاهب اسلامى فر آيند مزبور را به شرطى مجاز مىدانند كه رضايت شوهر

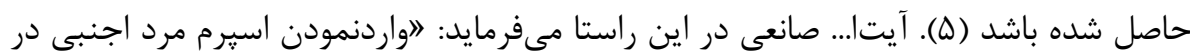
رحمم زن مسلمانى كه شوهرش عقيم است، حرام است، لكن براى رفع مشكل نداشتن فرزند

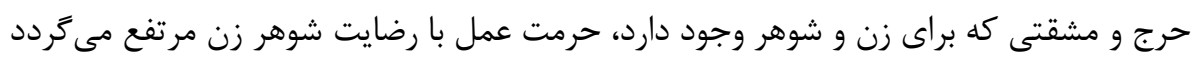

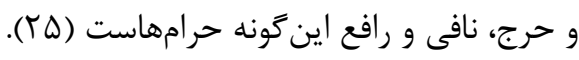


سال يازدهم، شماره جهلودوم، پياييز

با توجه به مستندات مطروحه كه درباره مشروعيت يا عدم مشروعيت بارورى توسط كامت بيكانه ارائه كرديد، نتايج ذيل به دست مست آمده است:

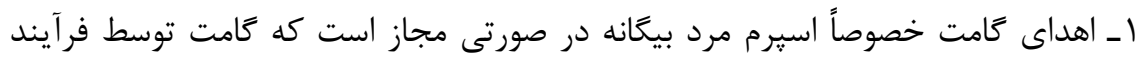
خارج رحمى منتقل شده باشد. r- بعضى از فقها كه قائل به حرمت هستند با بـا عنايت به وضعيت اسفناك خانوادههاى

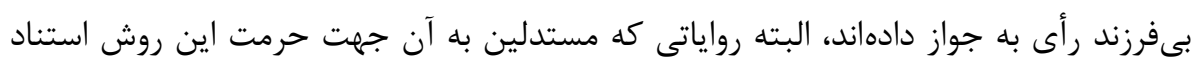
كردهاند، مربوط به بحث زناست و دلالتش بر حرمت اين مسأله قاصر است.

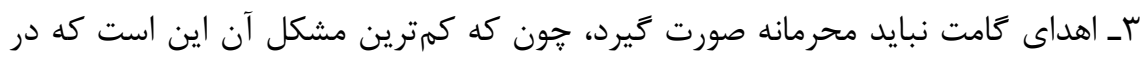

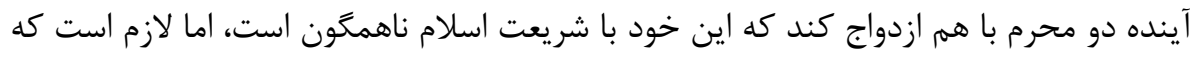

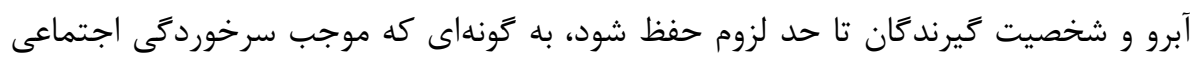
زوجين، به خصوص مرد نشود.

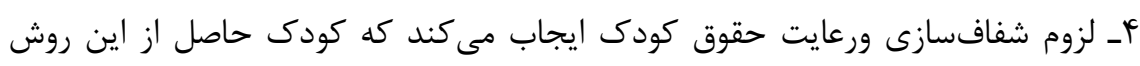
حق داشته باشد كه از نحوه يِدايش خود مطلع كردد، يس بر مراكز بارورى فرض است كه كليه

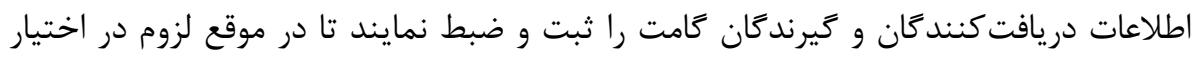

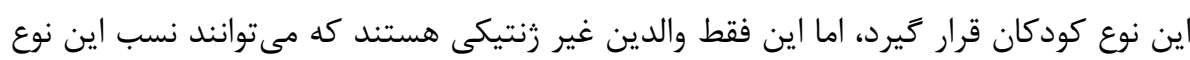
كودكان را هويدا نمايند نه اشخاص ديكر. هـ استفاده از اين روش دخالت در كار خداوند نيست و با كرامت انسانى تضاد ندارد، اما بايد دهايد

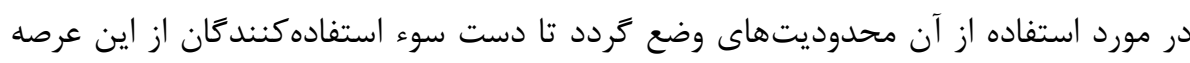
كوتاه گردد، فلذا نقش مراكز بارورى بسيار حائز اهميت است.

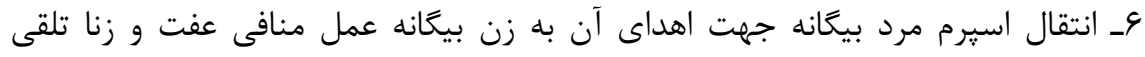

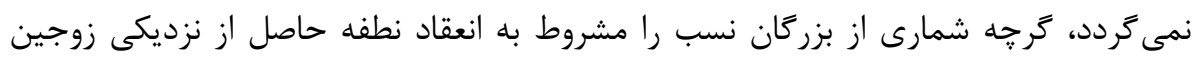
دانستهاند، اما در اين فر آيند نيز مىتوان نسب طفل را محفوظ داشت.

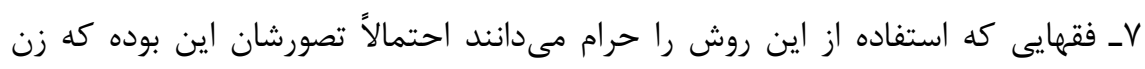

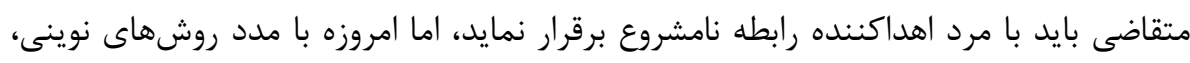
جون In Vitro و In Vivo، اصلاً بحثى از ارتباط زن با مرد اهداكننده وجود ندارد، بلكه تمام 


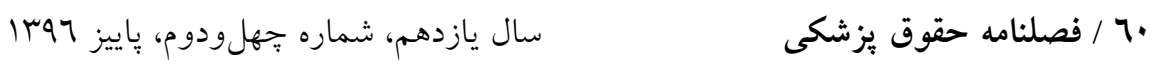

مراحل در محيط آزمايشعاه انجام مىيذيرد. بنابراين مىتوان از كامت بيكانه بدون مواجه فيزيكى بهره برد.

^ـ در مورد حكم تكليفى اهداى گامت، جهار نظريه از سوى فقهاى اسلامى ارائه كرديد كه

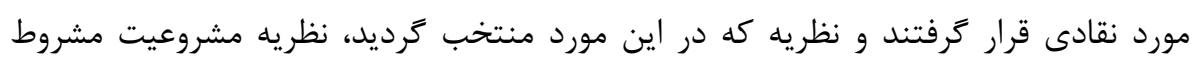

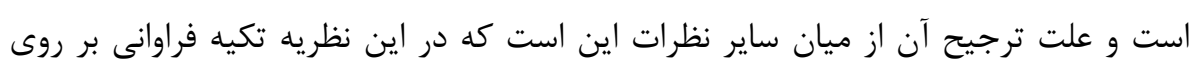

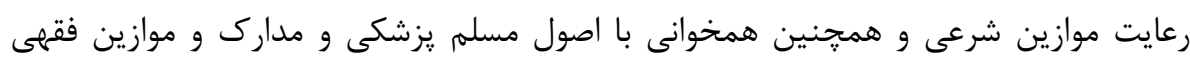

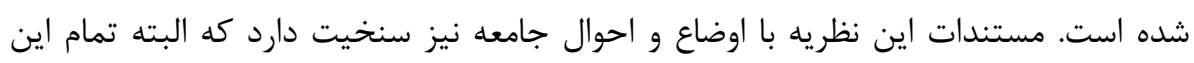
فرآيند بايد تحت نظارت متخصصين انجام يذيرد. 
سال يازدهم، شماره جهلودوم، باييز

\section{References}

1. Keye W, Chang R, Rebar W, Soules R. Unfertility, assessment and treatment. Translated by Karimzadeh MA, Falahatiyan A, Taheri R, Firouzabadi R. Yazd: Yazd Publication Institution; 1997. p.7. [Persian]

2. Frith L. Gamete Donation and Anonymity, the ethical and Legal debate. Human Reproduction 2001; 16: 818. [Persian]

3. Dehkhoda A. Dictionary. Tehran: University of Tehran; 1958. [Persian]

4. Hor Ameli M. The means of the Shiite to collect Sharia issues. Beiroot: Darahia Arab heritage; 1992. [Arabic]

5. Salameh ZH. Children's Ties between Science and Science. Beiroot: Darahia Arab heritage; 1981. p.71. [Arabic]

6. Basam MA. Children of Pipes. Islamic Jurisprudence Council Journal 1977. 1: 367. [Arabic]

7. Ahmad A. New in Fattawi disease and human infertility. Ordon: Darolforghan; 1994. p.8-21. [Arabic]

8. Fazel Lankarani M. Collector issues. Qom: Amin Publication; 1998. Vol.1. p.568. [Persian]

9. Makarem Shirazi N. A collection of a referendum message .Qom: The School of Emam Ali bin Abitaleb; 2002. Vol.2. Chapter.50. [Persian]

10. Davish A. Fatwa collection. Qatar: Qatar State Magazine; 1980. p.518. [Arabic]

11. Fakhr Razi M. Mafatihol Gheib. Qom: School of Ala'al al-Islam; 1993. Vol.6. p.297. [Arabic]

12. Hram Panahi SM. Artificial insemination. Ahle Beit Jurisprudence: Institution of Islamic jurisprudence (PBUH) 1997; 3(9-10): 130. [Persian]

13. Ebrahim Qomi HA. Qomi Interpretation. Qom: Darol Ketab Institution; 1986. Vol.2. p.101. [Persian]

14. Rohani MS. Al-Masal al-Mustawada. Qom: Darol etab Instiution; 1995. p.8-9. [Persian]

15. Moaayed H. Issues of inferred jurisprudence. Qom: Shahid Printing; 2008. p.12. [Persian] 
سال يازدهم، شماره جهلودوم، باييز 9741

16. Tabatabaee SMH. Almizan Interpretation. Translated by Musavi SMB. Qom: Islamic Publuication Office dependent on the community of lecturers in the seminary of Qom; 1996. Vol.15. p.15. [Persian]

17. Noori MH. Mustardak al-Wasael and Musta'nat al-Masa'il. Qom: Alolbeit Institution; 1987. Vol 14. p.335. [Arabic]

18. Qomi MM. Mustardak al-Wasael and Musta'nat al-Masa'il. Qom: Nashrol eslami Publication; 1995. p.81-83. [Persian]

19. Khoyee SA. Referendum. Qom: Foundation to revive the ruins of Khoyee; 2002. Vol.11. p.126. [Persian]

20. Shaltoot M. Ftwas. Qahere. Darol Fekr; 1990. p.213. [Arabic]

21. Deibol Bagha M. The system of Islam in the Apha and ethics and legislation. Beiroot: Darolfekr; 1998. p.213. [Arabic]

22. Vahid Khorasani H. Clarify Issues. Qom: Bagherol oloom School; 2000. p.2898. [Persian]

23. Qaem O. Rulings of the fetus in Islamic Jurisprudence. Beiroot: House of Andalusia; 2001. p.281. [Arabic]

24. Tantavi A. Alsoodi Fatwas. Beiroot: Darolmanah; 1999. p.103. [Arabic]

25. Saneyee Y. Pezeshki Surveys. Qom: Meysam Tamar; 1998. p.110-130. [Persian]

26. Bar MA. Industrialization and pipes. Journal of Islamic Fatwas comlex 1987. 1: 289. [ Arabic]

27. Javad A. Detailed in the history of the Arabs before Islam. Beiroot: Darolelm lelmalaeen; 1968. Vol.5. p.538. [Arabic]

28. Jafari MT. Letters of jurisprudence. Tehran: Manshoorate Keramat Institution; 1999. Vol.1. p.307. [Persian]

29. Abdol Eslam MH. Dictionary of language measures. Qom: School of Alaal al-Islami; 1984. Vol. p.478. [Arabic]

30. Safi Golpayegani L. The guidance magazine. Qom: The guidance magazine; 1992. p.222. [Persian]

31. Najafi MH. Jawaher al-Kalam in explaining the laws of Islam. Beiroot: Darahia Arab heritage; 1981. Vol. 29. p.258. [Arabic] 
سال يازدهم، شماره جهلودوم، باييز س7 / فصلنامه حقوق بزشكى

32. Sadr SM. Beyond the doctrine. Beiroot: House of Lights; 1966. Vol.11. p.6. [Arabic]

33. Raoul Duval A, Letur konirsch H, Frydman R. Aninymous OOcyte donation: A Psychological study of Recipient. Donors and children. Human Reproduction 1992; 7: 51-54.

34. McGee G, Brakman S, Gurmankin A. Gamete donation and Anonymity disclosure to children conceived with donor gamete should not be optional human Reproduction. Hum Reprod 2001; 16(10): 2033-2036.

35. Majlesi MB. Baharol-Anvar. Beiroot: Publication of Alvafa Institution; 1987. Vol.74. p.6-7, 15. [ Arabic]

36. Hakim MT. The General Principles of Comparative Jurisprudence. Beiroot: Andalus House; 1963. p.39. [Persian]

37. Koleini MY. Osoolol Kafi. Beiroot: Dar Al-Fakr al-Mu'aser; 1982. Vol.5. p.541. [Arabic]

38. Reza Nia Moaalem MR. Simulation of scientific, ethical, legal and jurisprudential considerations. Qom: Boostan Book; 2004. p.159. [Persian]

39. Mohamadi A. Simulation of scientific, ethical, legal and jurisprudential considerations. Qom: Authority of the Supreme Leader; 1999. p.200. [Persian]

40. Korgovi AP. Classical Classes in Medical Ethics. Tehran: Ministry of Health; 1994. p.115.

41. Helli FM. Explain the benefits in explaining the problems of rules. Qom: Esmaiilian Publication؛ The first printing; 2008. Vol.4. p.469. [Arabic]

42. Pakard V. Adasazan. Translated by Afshar Hassan. Tehran: Behbahani Publication; 1991. p.278. [Persian]

43. Emami A. A comparative study of the percentage of Iran and France. Tehran: Publication of Tehran University; 1979. p.367. [Persian]

44. Janati ME. Message clarifying issues. Qom: Ansariyan; 2003. p.500. [Persian]

45. Khameneyee SA. Medical in the mirror of ijtihad. Qom: Ansariyan publication! the first printing; 1996. p.282. [Persian] 
سال يازدهم، شماره جهلودومم، باييز 97\%

46. Yazdi M. Artificial fertility and its jurisprudential ruling. Ahl al-Bayt Jurisprudence Magazine 1997; 2(5-6): 105. [Persian]

47. Motahari A. Editorial. Qom: Dar Alalem Publications; 2002. p.190. [Persian]

48. Beyhaghi AB. Sanan al-Kubri. The achievement of Mohammed Abdul Qadir Atta. Mecca: Daralbaz Office; 1993. Vol.4. p.368. [Arabic]

49. Heathami A. Complex of appendages. Beiroot: Arabic Bookshop; 1987. Vol. 5. p.85. [Arabic]

50. Georgi AQ. A comparative study of family law. Tehran: Publication of Tehran University; 2005. p.431. [Persian]

51. Mostafavi SK. Mae Al-Fiqahi's Rule. Qom: Al Ma'darsin Society of Qom Seminary; 2001. p.298. [Persian]

52. Maghrebi Tamimi N. Prayer for Jesus .Qom: Al-Alibat Institute (AS); 2006. Vol.1 p.309. [Arabic]

53. Hosseini Sistani SA. Al-Masal al-Montaya. Qom: Ayatollah Sayyid Ali Sistani School; 2002. Vol.1. p.765. [Persian]

54. Tabatabai MH. Islamic jurisprudence and jurisprudence. Najaf: Darulahalal; 2000. Vol.2. p.51. [Persian]

55. Jaafari H. Investigation of Male Infertility, Diagnosis and Treatment. Tehran: Hayan; 2003. p.191. [Persian]

56. Golpayegani MR. Treatise on the explanation of Al-Masaleh. Qom: Darul Quran al Karim; 2004. Vol.2. p.52. [Persian]

57. Tabrizi MJ. New essay. Qom: Sarv Publication; 1991. p.2120. [Persian] 